\title{
Cultivating Intellectual Safety in a Women and Leadership Course
}

\author{
S. Lynn Shollen \\ Christopher Newport University \\ Newport News, VA 23606 \\ lynn.shollen@cnu.edu
}

\begin{abstract}
This application brief provides pedagogical strategies for teaching and learning about women and leadership as a potentially sensitive subject, with emphasis on creating an intellectually safe learning environment. Findings from a study of students' expectations and experiences with a Women and Leadership course showed that the strategies affected students' learning experiences. Some strategies also challenged the instructor as a woman leader.
\end{abstract}

\section{Introduction}

Formal teaching about women and leadership is becoming more common within higher education curricula and leadership development programs in response to the call for a more complex understanding of leadership beyond traditional, heroic conceptions, and to address the demand for gender diversity in formal leadership roles and for enhanced development of leaders regardless of gender. However, leadership educators may not consider the pedagogical implications of teaching a gender-focused course. Scrutinizing gender-related issues can be considered taboo by faculty and students (Crosby, 2012; Lusk \& Weinberg, 1994; Rusch, 2004). Challenging matters are bound to arise when exploring women and leadership, such as genderbased stereotyping; differences in personal experiences with, perceptions of, and beliefs about gender and leadership; and issues of first- and second-generation gender bias. Further, many topics relevant to women and leadership are grounded in issues of power, privilege, and difference-issues which are themselves sensitive and can elicit confusion, blame, denial, and resistance (Johnson, 2001). It can be difficult to engage with such issues from a socio-structural perspective and resist personalizing discussions (Bohmer \& Briggs, 1991). Because women and leadership may be sensitive to explore, it is essential that exploration can occur in an environment purposefully crafted with the potential challenges in mind. Literature addresses teaching relevant to sensitive identities such as gender and race, as well as the subject of women and leadership and developing women leaders, but there is little about teaching women and leadership as a potentially sensitive subject (see Shollen, 2015; Brown, Irby, Fisher, \& Yang, 2006; Debebe, 2011; Ely, Ibarra, \& Kolb, 2011). In this paper, I discuss pedagogical strategies that have been effective for cultivating a learning environment in which students have felt comfortable engaging with the subject of women and leadership, and have experienced meaningful, and at times transformative, learning. 


\section{Teaching Sensitive Subjects}

Educators are responsible for providing an environment for students to learn how to grapple with sensitive issues. Such a learning environment would ideally, and perhaps necessarily, be an intellectually safe one (Cherrin, 2004). Contrary to how it sounds, an intellectually safe environment does not discourage students from challenging their assumptions or shelter them from provocative or disruptive perspectives (Boostrom, 1998; Shulevitz, 2015); rather, it is an environment that invites students to the challenge of learning in a way that works for them. An intellectually safe environment provides "an open and comfortable atmosphere in which students feel free to express their thoughts, feelings, or opinions without fear of retribution from instructors or peers" (Call, 2007, p. 28). It is an environment of hospitality that includes elements of care, openness, motivation, mutual respect and accountability, and engagement (Palmer, 1993). Teachers who both challenge and support students, emphasize social inclusion, and honor students' different experiences help to create an intellectually safe learning environment (Kolb \& Kolb, 2005). In such environments, teachers share authority, allow room for uncertainty, engage students in collaborative knowledge construction and meaning making, and value diverse opinions and experiences (Schrader, 2004). In environments perceived as safe, students can learn more and be more challenged to grow personally, as well as be more likely to learn about others, expand their views, increase their self-awareness, and develop effective communication skills (Holley \& Steiner, 2005).

Numerous approaches to teaching, many of which include components of creating an intellectually safe learning environment (see Holley \& Steiner, 2005), have been identified to help educators and students become more comfortable engaging with sensitive subjects. For example, Cherrin (2004) recommends achieving a balance of freedom and structure within the classroom, which entails the teacher providing a model of critical discourse by framing the social and moral issues, establishing ground rules for disagreement, setting the tone by which information is conveyed and discussion is held, encouraging initial participation, and tempering conflict and bias. Gilbert and Eby (2001) endorse creating trust that fosters a strong sense of classroom community (including collaboratively establishing ground rules for respectful communication), avoiding formal lectures, fostering inclusive large and small group discussions, assigning both individual and group tasks, using gentle humor, listening to students' opinions, and addressing any barriers that arise with individuals or the entire class. They also suggest that teachers must be comfortable with and have a secure knowledge of the sensitive material and corresponding issues in order to employ these strategies effectively. Lusk and Weinberg concluded that "by asking students to take a more sociological [rather than individual] perspective on classroom dynamics, we enable the group to recreate the classroom environment so that dissent and disagreement can exist along with mutual respect" (1994, p. 307). Numerous other approaches to teaching sensitive topics have been detailed (e.g., Cotton, 2006; Crosby, 2012; Jakubowski, 2001; Pace, 2003). Although there are many approaches to help teachers more confidently and successfully engage themselves and students in examining sensitive topics, the strategies may or may not play out as well in the classroom depending on the individual teacher and students, their collective relationship, and the classroom environment.

Most literature that focuses on teaching and learning specifically relevant to women and leadership stems from research on women's leadership development programs. For instance, 
Debebe (2011) advocates having all-women learners and using gender-sensitive teaching and learning practices to create a safe environment that can foster transformational learning. Other leadership scholars and practitioners also support having all-women learners as a means of contributing to an intellectually safe environment by reducing gender-related constraints (Ely et al., 2011; Vinnicombe \& Singh, 2002; Willis \& Daisley, 1997). However, the single-gender approach to women's leadership development is controversial (e.g., Fletcher, 1998; Gray, 1994; Vinnicombe \& Singh, 2002).

Literature on teaching about women and leadership in a higher education setting is scant. Although Brown and colleagues (2006) do not name women and leadership as a sensitive subject, they describe an andragogical approach to teaching a graduate course on women in educational leadership that involves setting a climate of learning that is self-directed, learnercentered, mutually respectful, collaborative, and informal. Shollen (2015) found that undergraduate students perceive women and leadership as a sensitive subject and expect both struggle and meaningful learning from its study. Further, students are able to deal with struggles and experience meaningful, and at times transformative, learning in part because of the presence of an intellectually safe learning environment. In the next section, I describe the pedagogical strategies used to cultivate such an environment.

\section{Pedagogical Strategies for Teaching Women and Leadership}

In this section, I describe the pedagogical strategies that I practice while teaching an elective course that I designed titled Women and Leadership, as part of the Leadership Studies minor curriculum at a liberal arts institution (see Shollen, 2015 for course description). For four semesters thus far, the course has been held in a traditional classroom with an average enrollment of 25 undergraduate students. The large majority of students identified as women and were of junior or senior standing; all were of traditional college age and pursuing a minor in [minor name]. My strategies for teaching Women and Leadership are driven by my pedagogical imperative to create an intellectually safe learning environment for students to explore a potentially sensitive subject. Indeed, at the beginning of the course, students anticipated struggling with conflicting views and confrontation, including discussions being taken personally, as well as with potentially narrow content and approach to the course. Students used language such as controversial, heated, rough spots, touchy or "hot button" topics, intense, difficult, challenging, and tough to convey their anxieties (Shollen, 2015).

Choices about course design can help to ease students' anxieties and foster an intellectually safe learning environment. Regarding content, I include a wide range of topics as well as readings that offer a variety of perspectives on a topic. Although this approach is common in course design, including a variety of topics and perspectives for a sensitive subject may be even more important so that students do not feel an ideological agenda or prescribed perspective pushed upon them. For instance, early in the semester we interrogate whether we should be gendering leadership, if feminism is relevant to the discussion of women and leadership, and where men fit into the conversation. Regarding structure, I try to engage students with different learning styles by designing class sessions and assignments to include short lectures, small and large group discussions, video clips, guest speakers, in-class reflective writing, active learning activities, public class blog contributions, interview papers, and a 
creative final project with presentation. To align with signature pedagogies identified for undergraduate leadership education, open, inclusive discussions are integrated into every session (Jenkins, 2012; Odom, 2015).

Beyond course design choices, creating an intellectually safe learning environment requires a collaborative effort with students. They are equally responsible, and deserve equal credit, for upholding such a space once they understand what it "looks like." As the formal leader, it is my responsibility not only to articulate and model a safe environment, but also to help students understand their role in maintaining such an environment, since they may not be aware of the shared responsibility (Holley \& Steiner, 2005). To that end, I provide and review with students a detailed syllabus - written using "I," "we," and "you" to suggest a shared, personalized course experience - that explicitly describes a classroom philosophy that emphasizes mutual respect and openness to others' views, as well as clear expectations for classroom behavior, participation, and assignments. Throughout the semester, I uphold the classroom philosophy by modeling a supportive communication climate (Levi, 2014), in which all voices are equally invited and heard, every comment is respectfully considered, critiques are constructive, discussions are about being open to perspectives rather than about controlling, and ideas can be tested without overconfident conclusions being prematurely drawn. Further, at times I (rarely) have to enforce the philosophy by having private conversations with students who are not adhering to it and are endangering the learning environment for others. I also learn all students' names quickly; I start the second class session by naming each student aloud. This practice sets the tone of respect and community early, helps me to earn students' trust, and shows them that they are important as individuals.

To further establish the classroom culture early on and engage students in the co-creation of a safe learning environment, I solicit students' concerns and allow their voices to be heard. I ask them to privately write their expectations and concerns about the course on the first day; the following session, I provide a typed handout of their anonymous responses for the entire class to discuss. Putting the elephants out in the room may relieve anxiety; students can see that others have similar concerns and that I take their apprehensions seriously. For instance, we addressed concerns about narrow content by making a list of topics that students wished to see included, and worked to integrate them during the semester. We addressed concerns about conflicting viewpoints and discussions being taken personally by revisiting the classroom philosophy and talking about societal-level versus individual-level constructions and issues. We also addressed concerns about generalizing by having a conversation about the cognitive reasons for stereotyping (Brewer, 1996), and the pros and cons of doing so. Further, we agreed to acknowledge when we were generalizing or stereotyping; for example, one might say "This may not be true for all women, but women typically struggle to claim power." My listening to their trepidations and experiences becomes the norm as we repeatedly revisit those that are relevant throughout the semester at appropriate times. I also hear students' voices when I ask them for candid, constructive, formative feedback at mid-semester, review the themes from the feedback anonymously with the class, and make reasonable changes accordingly.

Another way by which I create a safe learning environment is by disarming students with me, the teacher as flawless and all-knowing authority figure (Brookfield, 1995). I invite them to see behind the curtain of my decisions and thinking. For example, why did I choose to include 
or exclude a topic? Is this assignment structured in the most fair and useful way to assess their learning? What do I see as the purpose of a public blog? In some situations, I ask them to weigh in publicly or privately on decisions. I make the final call, but I work to empower students as much as possible so that they have agency in their learning experience. I am also comfortable letting students see me grapple with complex ideas and controversial topics, while doing my best to keep my personal opinions out of the discussion. It is important for students to understand that we are all learners, and that learning is messy for all of us. I encourage students to constructively challenge the perspectives that $I$, their peers, or the readings present (which can also be believed as sources of all-knowing authority), and ensure that they can do so without punishment. I may assign the role of devil's advocate to an individual or group so that we are collectively required to consider alternative perspectives when it may be uncomfortable to challenge authority or the majority. This practice is particularly useful when the majority is failing to check its assumptions about preferred choices or behaviors. For example, some students may feel silenced when the majority assumes that it is "right" for educated women to pursue both career- and family-related goals and not be "just" a stay-at-home mother.

Another strategy that allows students to feel intellectually safe in the Women and Leadership course is how I evaluate class participation. My study of and experience with the personality trait of introversion has changed how I approach evaluating class participation in all of my courses. Introverts tend to think before they speak, prefer listening to talking, prefer to express themselves in writing than verbally, and may be more likely than extraverts to experience communication apprehension (Cain, 2012; Opt \& Loffredo, 2000). I noticed my own bias in past courses; students who spoke out more often received higher participation grades. Now when we review the syllabus, I explain my expectations for participation and my understanding that different people actively participate in different ways. To allow students a forum to participate in ways that work for them, I include plenty of opportunities for discussion in pairs, small groups, and large group, and also time for individual reflection. Although it is important to meet students where they are regarding their participation preferences and perceived meaning of participation (Fritschner, 2000), I also establish a norm for some level of verbal participation and challenge students to push themselves by participating outside of their comfort zone at least once per week. When students speak up who typically do not, I am sure to invite their voices into the discussion and acknowledge their points (and sometimes constructively reframe the points if not on-target or to enhance relevance) in order to provide positive feedback for the courageous act. I also encourage participation by having students move around the classroom to engage with different people in different spaces. Contrary to some advice for teachers that "moving confidently around a classroom 'marks' it as your territory" (Elliott, 2012, p. 107), I purposefully move around the entire classroom space and encourage students to do so at times as a message that it is our collective learning space.

\section{Potential Outcomes of Pedagogical Strategies}

Approaching the Women and Leadership course as a sensitive subject and utilizing the pedagogical strategies described played a role in students' learning experiences, as demonstrated by findings from a qualitative study of students' expectations and experiences during two semesters of the course (Shollen, 2015). Students indicated that our approach to the course mitigated their initial concerns of struggle and helped them to engage in a meaningful learning 
experience; further, many described experiencing transformative learning. In addition, my approach to the course instigated challenging decisions for me as a woman leader.

Most students actualized their anticipations of meaningful learning, and many emphasized the positive influence that the intellectually safe learning environment had on their learning experiences. For example, our collective work to maintain a culture of intellectual safety enabled students to more fully participate in the learning process by feeling comfortable expressing their ideas and listening openly to others' perspectives. One student noted that the environment helped her move from fear to engagement: "When I first walked into the classroom and became more aware about the depth and heaviness of the content, I considered dropping the course altogether. I did not know if I would be able to participate...luckily, the class environment was supportive and open to different viewpoints." Other students remarked that the environment helped them to feel more confident having future difficult discussions.

Not only were students more able to engage in learning in part because of the intellectually safe environment, many articulated their experiences of meaningful learning as transformative. Students' responses to questions about their experiences with the course indicated a shift in their ways of knowing, such that they revised their taken-for-granted frames of reference to be more open, discriminating, and reflective (Mezirow, 2000). For instance, one student remarked "I really did not care about women and leadership and had quite a large bias against feminism or anything relating to it. But...I have gained exponential knowledge and really been challenged. There have been few other courses that have really made me question my assumptions and challenge my actions as this class." Transformative learning is more likely to occur in environments perceived as safe, because deep change typically elicits anxiety (Edmondson, 1999; Mezirow, 1991).

Although students did not explicitly note components of course design as a means of fostering an intellectually safe learning environment, design choices also affected their experiences. They appreciated the opportunity for exploration provided by the selection of course content. More topics, issues, and perspectives were integrated into classes and discussions than they expected, and with depth beyond what they anticipated. Students also valued the course structure that allowed them to learn from others and hear a variety of perspectives through different assignments, speakers, and collaborative discussions.

Despite the positive effects for students, the approach I have described for teaching Women and Leadership posed challenges to me as the teacher, beyond the course involving a potentially sensitive subject. One significant challenge is the question of how much to try to share power with students, at the risk of losing control as the ultimately responsible authority figure - a question that is complicated by gender. Crafting the classroom as a space of mutual influence and learning between student and teacher disrupts the normative practice of teacher as all-knowing sage (Brookfield, 1995). As a woman leader in the classroom, I was also concerned about establishing and maintaining students' respect, given the necessity for women leaders to be seen as both competent and likeable in order to be perceived as effective (Eagly \& Carli, 2007). Women teachers who wish to be effective cannot be perceived as push-overs by giving students too much power; yet, as aligned with gendered expectations, we may tend toward enacting power as "with" versus “over" students (Baker Miller, 1987). I manage this challenge by setting a tone 
of mutual respect from the beginning of the course, holding high expectations, establishing boundaries on relationships and personal information, and not coddling students while also being supportive and fair. I purposefully come off firmer at the beginning of the course, and lighten up over time as mutual respect becomes the norm.

\section{Conclusion}

Leadership educators and students can benefit from recognizing women and leadership as a potentially sensitive subject. Many of the strategies that I have found useful and successful when developing and teaching a Women and Leadership course have been documented for teaching sensitive topics and creating intellectually safe spaces, but have not yet been considered relevant for teaching about women and leadership. Given the qualities of an intellectually safe learning environment, it could be argued that cultivating such an environment is essentially a component of feminist pedagogy (Shrewsbury, 1993), and perhaps essential for transformative learning, which is likely a goal of teaching about women and leadership.

The strategies I have presented are what have worked for me, teaching a specific course at one institution, with a particular type of students. These strategies may not be effective for other courses, at other institutions, or with other teachers and students. I also cannot attest to the effects of my personality and natural style, or the role that the students and their qualities may have intentionally or unintentionally played in the process. Ultimately, creating an intellectually safe learning environment for teaching about women and leadership - or any sensitive subject is an individualized, yet shared, context-specific endeavor between teacher and students, and is more a work of art than a collection of strategies.

\section{References}

Shollen. (2015).

Baker Miller, J. (1987). Women and power. Women and Therapy, 6(1-2), 1-10.

Bohmer, S., \& Briggs, J. L. (1991). Teaching privileged students about gender, race, and class oppression. Teaching Sociology, 19(2), 154-163.

Boostrom, R. (1998). Safe spaces: Reflections on an educational metaphor. Journal of Curriculum Studies, 30(4), 397-408.

Brewer, M. B. (1996). When stereotypes lead to stereotyping: The use of stereotypes in person perception. In C. N. Macrae, C. Stangor, \& M. Hewstone (Eds.), Stereotypes and stereotyping (pp. 254-275). New York: The Guilford Press.

Brookfield, S. (1995). Becoming a critically reflective teacher. San Francisco: Jossey-Bass. 
Brown, G., Irby, B. J., Fisher, A., \& Yang, L. (2006). Using the andragogical model for a graduate course in educational leadership. The Delta Kappa Gamma Bulletin, Winter, 3262.

Cain, S. (2012). Quiet: The power of introverts in a world that can't stop talking. New York: Crown.

Call, C. M. (2007). Defining intellectual safety in the college classroom. Journal on Excellence in College Teaching, 18(3), 19-37.

Cherrin, S. (2004). Teaching controversial issues. The Professional and Organizational Development Network in Higher Education.

Cotton, D. R. E. (2006). Teaching controversial environmental issues: Neutrality and balance in the reality of the classroom. Educational Research, 48(2), 223-241.

Crosby, D. B. (2012). Meeting the challenge: Teaching sensitive subject matter. The Journal of Effective Teaching, 12(2), 91-104.

Debebe, G. (2011). Creating a safe environment for women's leadership transformation. Journal of Management Education, 35(5), 679-712.

Eagly, A. H., \& Carli, L. L. (2007). Through the labyrinth: The truth about how women become leaders. Boston: Harvard Business Review Press.

Edmondson, A. (1999). Psychological safety and learning behavior in work teams. Administrative Science Quarterly, 44(2), 350-383.

Elliott, P. (2012). Communication in the classroom. In V. Brooks, I. Abbott, \& P. Huddleston (Eds.), Preparing to teach in secondary schools ( $3^{\text {rd }}$ ed., pp. $\left.103-116\right)$. Berkshire, England: Open University Press.

Ely, R. J., Ibarra, H., \& Kolb, D. M. (2011). Taking gender into account: Theory and design for women's leadership development programs. Academy of Management Learning \& Education, 10(3), 474-493.

Fletcher, J. K. (1998). Relational practice: A feminist reconstruction of work. Journal of Management Inquiry, 7(2), 163-186.

Fritschner, L. M. (2000). Inside the undergraduate college classroom: Faculty and students differ on the meaning of student participation. The Journal of Higher Education, 71(3), 342362.

Gilbert, P. R., \& Eby, K. K. (2001). Blowing the teachers away: Teaching controversial and sensitive issues to undergraduates. Journal on Excellence in College Teaching, 12(2), 3754. 
Gray, B. (1994). Women-only management training: A past and present. In M. Tanton (Ed.), Women in management: A developing presence (pp. 202-228). London, England: Routledge.

Holley, L. C., \& Steiner, S. (2005). Safe space: Student perspectives on classroom environment. Journal of Social Work Education, 41(1), 49-64.

Jenkins, D. M. (2012). Exploring signature pedagogies in undergraduate leadership education. Journal of Leadership Education, 11(1), 1-27.

Jakubowski, L. M. (2001). Teaching uncomfortable topics: An action-oriented strategy for addressing racism and related forms of difference. Teaching Sociology, 29(1), 62-79.

Johnson, A. G. (2001). Privilege, power, and difference. (1 ${ }^{\text {st }}$ ed.). New York: McGraw-Hill.

Kolb, A. Y., \& Kolb, D. A. (2005). Learning styles and learning spaces: Enhancing experiential learning in higher education. Academy of Management Learning \& Education, 4(2), 193 212.

Levi, D. J. (2014). Group dynamics for teams (4 ${ }^{\text {th }}$ ed.). Thousand Oaks, CA: Sage Publications.

Lusk, A. B., \& Weinberg, A. S. (1994). Discussing controversial topics in the classroom: Creating a context for learning. Teaching Sociology, 22(4), 301-308.

Mezirow, J. (1991) Transformative dimensions of adult learning. San Francisco: Jossey-Bass.

Mezirow, J. (2000). Learning to think like an adult: Core conceptions of transformation theory. In J. Mezirow (Ed.), Learning as transformation: Critical perspectives on a theory in progress (pp. 3-33). San Francisco: Jossey-Bass.

Odom, S. F. (2015). Undergraduate student perceptions of the pedagogy used in a leadership course: A qualitative examination. Journal of Leadership Education, 14(2), 17-29.

Opt, S. K., \& Loffredo, D. A. (2000). Rethinking communication apprehension: A Myers-Briggs perspective. The Journal of Psychology, 134(5), 556-570.

Pace, D. (2003). Controlled fission: Teaching supercharged subjects. College Teaching, 51(2), 42-45.

Palmer, P. (1993). To know as we are known. San Francisco: HarperOne.

Rusch, E. A. (2004). Gender and race in leadership preparation: A constrained discourse. Educational Administration Quarterly, 40(1), 14-46. 
Schrader, D. E. (2004). Intellectual safety, moral atmosphere, and epistemology in college classrooms. Journal of Adult Development, 11(2), 87-101.

Shrewsbury, C. M. (1993). What is feminist pedagogy? Women's Studies Quarterly, 21(3/4), 816.

Shollen, L. (2015). Teaching and learning about women and leadership: Students' expectations and experiences. Journal of Leadership Education, 14(3), 35-52.

Shulevitz, J. (2015, March 21). In college and hiding from scary ideas. New York Times Sunday Review. Retrieved April 12, 2015 from:

http://www.nytimes.com/2015/03/22/opinion/sunday/judith-shulevitz-hiding-from-scaryideas.html?smid=fb-nytimes\&smtyp=pay\&smvar=mapkwp\&ad-

keywords=instagram \&kwp_0 $=12785 \& \mathrm{fb} \_r e f=D e f a u l t \& f b \_s o u r c e=m e s s a g e \& \_r=0$

Vinnicombe, S., \& Singh, V. (2002). Women-only management programs: An essential part of women's leadership development. Journal of Change Management, 3(4), 294-306.

Willis, L., \& Daisley, J. (1997). Women's reactions to women-only training. Women in Management Review, 12(2), 56-60.

\section{Author Biography}

Dr. S. Lynn Shollen is Assistant Professor of Leadership Studies in the Department of Leadership and American Studies at Christopher Newport University, Newport News, Virginia. Her research interests include identity and perceptions of leadership, the effects on identity of the transition from faculty to academic administrator, teaching about women and leadership, and leadership identity construction. Her early research focused on faculty mentoring, particularly for women and racial minority faculty, including those interested in pursuing administrative leadership roles. Dr. Shollen co-authored the book Faculty Success Through Mentoring: A Guide for Mentors, Mentees, and Leaders (2009). She serves on the Executive Leadership Team of the International Leadership Association's Women and Leadership Affinity Group, as a reviewer for Journal of Leadership Education and Leadership, and on the advisory board for Christopher Newport University's Center for Effective Teaching. 